\title{
Performance of NCAR Regional Climate Model in the Simulation of Indian Summer Monsoon
}

\author{
Gyan Prakash Singh ${ }^{1 *}$ and Jai $\mathrm{Ho} \mathrm{Oh}^{2}$ \\ ${ }^{I}$ Department of Geophysics, Banaras Hindu University, Varanasi-221005, India \\ ${ }^{2}$ Integrated Climate System Modeling Group, Department of Environmental Atmospheric Sciences, \\ Pukyong National University, 599-1 Daeyeon3-dong, Nam-gu, Busan 608-737, Korea \\ (Received May 12, 2010; Revised September 15, 2010; Accepted September 16, 2010)

\section{NCAR 지역기후모형의 인도 여름 몬순의 모사 성능} \\ Gyan Prakash Singh ${ }^{1 *}$ 오재호 ${ }^{2}$ \\ ${ }^{1}$ Department of Geophysics, Banaras Hindu University, Varanasi-221005, India \\ 2부경대학교 환경대기과학과 \\ (2010년 5월 12일 접수; 2010년 9월 15일 수정; 2010년 9월 16일 수락)
}

\begin{abstract}
Increasing human activity due to rapid economic growth and land use change alters the patterns of the Asian monsoon, which is key to crop yields in Asia. In this study, we tested the performance of regional climate model (RegCM3) by simulating important components of Indian summer monsoon, including land-ocean contrast, low level jet (LLJ), Tibetan high and upper level Easterly Jet. Three contrasting rain years (1994: excess year, 2001: normal year, 2002: deficient year) were selected and RegCM3 was integrated at $60 \mathrm{~km}$ horizontal resolution from April 1 to October 1 each year. The simulated fields of circulations and precipitation were validated against the observation from the NCEP/NCAR reanalysis products and Global Precipitation Climatology Centre (GPCC), respectively. The important results of RegCM3 simulations are (a) LLJ was slightly stronger and split into two branches during excess rain year over the Arabian Sea while there was no splitting during normal and deficient rain years, (b) huge anticyclone with single cell was noted during excess rain year while weak and broken into two cells in deficient rain year, (c) the simulated spatial distribution of precipitation was comparable to the corresponding observed precipitation of GPCC over large parts of India, and (d) the sensitivity experiment using NIMBUS-7 SMMR snow data indicated that precipitation was reduced mainly over the northeast and south Peninsular India with the introduction of $0.1 \mathrm{~m}$ of snow over the Tibetan region in April.
\end{abstract}

Key words : Summer monsoon, Regional climate model, Low level jet, Precipitation, Tibetan snow

\section{INTRODUCTION}

The first successful simulation of regional climate modeling (RCM) system is found in Dickinson et al. (1989) and Giorgi and Bates (1989). Giorgi et al. (1994) have shown that the precipitation distribution simulated by RCMs contains a strong orographically related component on the scales not resolved by the general circulation models (GCMs). Several studies have found that RCMs can generate more realistic regional climate details than the GCMs (Bhaskaran et al., 1996; Cocke and Law Row, 2000; Fenessy and Shukla, 2000; Mitchell et al., 2001; Nobre et al., 2001; and Roads et al., 2003a;). Dash et al. (2006) have sim-

* Corresponding Author: Gyan Prakash Singh (gpsinghbhu@hotmail.com) 
ulated the Indian summer monsoon rainfall (ISMR) with the National Centre for Atmospheric Research (NCAR) Regional Climate Model (RegCM version 2) using lateral boundary conditions from European Centre for Medium Range Weather Forecasts (ECMWF) product. Singh and Oh (2007) have examined the effect of warm sea surface temperature (SST) surrounding the Indian peninsula on seasonal monsoon circulation and ISMR with RegCM3. But the above studies have not examined the important elements of the South Asian monsoon systems such as LLJ at 850hpa, Land-Ocean contrast and upper level Tibetan High, and Easterly Jet. A comprehensive review of the latest progress and application of RCMs are given in Wang et al. (2004).

There are several studies to suggest that the anomalous cooling due to the positive snow mass anomalies in early spring over the Tibet Plateau (TP) tends to produce a weak Asian monsoon (Zwiers, 1993; Ose, 1996). It is well known that the size of the snow mass anomaly is one of the important factors affecting the model results. In a set of GCM experiments (Barnett et al., 1989), snow depth was set to $0.02 \mathrm{~m}$ of the water equivalent. In further experiment of Barnet (1989), the snowfall rate in the condensation schemes of the model was doubled and subsequently, a snow mass difference of $0.13 \mathrm{~m}$ was found over the extended region of Eurasia. In another study, Yasunari et al. (1991) added $0.05 \mathrm{~m}$ water equivalent of snow mass anomaly over the snow cover area over Eurasia. Vernekar et al. (1995) prescribed the light and heavy snow depth of $0.025 \mathrm{~m}$ and $0.10 \mathrm{~m}$ water equivalent to the model initially over Tibet based on NIMBUS snow depth data. Snow depth anomalies of $5 \mathrm{~cm}$ water equivalent were also used in the Meteorological Research Institute (MRI) GCM experiment (Ose, 1996) over three different regions (i.e. Tibet, Eastern Europe, and Siberia) on 1 March. Although a large number of sensitivity experiments have been conducted to study the effect of Eurasian/Tibetan snow on the Asian monsoon circulation, modelling studies investigating the impact of the Tibetan snow on ISMR are rare. With the recent developments in regional models including new physical scheme, cloud and precipitation processes, and new parameter for ocean flux scheme, it is appropriate to study the effect of the Tibetan snow on the circulation and associated ISMR using the latest version of RegCM3.

ISMR returns every year from June to September with remarkable regularity and provides the necessary water for crops and hydropower generation. Despite the remarkable consistency in the seasonal reversal of wind fields, ISMR shows considerable inter-annual variability (Parthasarathy et al., 1995). Best example is a recent drought of 2002 and excess rainfall in 1994. It is important to note that most of the droughts/floods over the Indian subcontinent were mainly related to El-Nino Southern oscillation (ENSO) and La-Nina events in the Pacific Ocean. In contrast to most of the previous droughts, the widespread decrease in rainfall during 2002 (especially in July) was not associated with ENSO events (Gadgil et al., 2002 and Singh et $a l ., 2005)$ and the excess rainfall in 1994 was not associated with La-Nina events, either (Chattopadhyay and Bhatla, 2002).

The objectives of the present paper are (1) to evaluate the performance of RegCM3 in simulating the Indian summer monsoon and (2) to study the effect of the spring Tibetan snow on the monsoon circulation and ISMR. Because of the difficulty in initializing snow depth accurately in the model, a uniformly distributed snow is used, although the initial snow depth is estimated from satellite observations. Our experiments are thus of illustrative in nature concerning the hypothesized snow cover-induced processes. It is important to note that ISMR of early period (June and July) does not show any significant correlation with latter part (August and September) (Gadgil et al., 2002). Annamalai et al. (1999) have shown that the substantial difference exists between NCEP and ECMWF reanalysis products, particularly around the Low Level Jet (LLJ) regions. Therefore, we have given focus mainly to July because June is the onset period for the Indian summer monsoon. The ISMR in July contributes major role in deciding the total seasonal monsoon conditions of drought, excess and normal rain years. In this paper, a brief description of RegCM3 model and the experimental design are given in Section 2. The important results of control and sensitivity runs are described in Sections 3 and 4, respectively. Finally, conclusions are presented in Section 5.

\section{MODEL DESCRIPTIONS AND EXPERIMENT DESIGNS}

The RegCM3 used in the present study is originally developed by Giorgi et al. (1993a, b) and then augmented and described by Giorgi and Mearns (1999) 
and Pal et al. (2000). The dynamical core of the RegCM3 is similar to the hydrostatic version of the NCAR/Pennsylvaia State University mesoscale model MM5 (Grell et al., 1994). Surface processes are represented via the Biosphere-Atmosphere Transfer Scheme (BATS) (Gao et al. 1996). Boundary layer physics is following the non-local vertical diffusion scheme of Holtslag et al. (1990). Different schemes are available for the generation of precipitation in RegCM3. Non convective precipitation is represented by an implicit scheme (Hsiel et al., 1984). Convective precipitation can be described using Grell scheme (Grell 1993). We have selected the Arakawa-Schubert closure, which yielded generally better results for our domain (Dash et al., 2006, Singh and Oh, 2008). Resolvable scale precipitation is represented via the scheme of Pal et al. (2000). Radiative transfer is computed using the radiation package of the NCAR Community Climate Model Version-3 (CCM3) (Kiehl et al., 1996).

The control and sensitivity experiments were conducted from 1 April to 1 October ( 6 months) for the years 1994, 2001 and 2002. The chosen years cover three different conditions of ISMR. The year 2001 can be considered as 'normal' (normalized rainfall lies within $\pm 1 \sigma$ ) rain year, while 2002 (below $-1 \sigma$ ) was characterized by deficient rain year and the year 1994 (above $+1 \sigma$ ) was the excess rain years. In all the experiments, the central longitude and latitude were centered at $75 \mathrm{E}$ and $25 \mathrm{~N}$ with $105 \times 100$ grid points along the latitude and longitude directions. The model domain covers the area approximately from $38^{\circ} \mathrm{E}$ to $110^{\circ} \mathrm{E}$ and from $5^{\circ} \mathrm{S}$ to $53^{\circ} \mathrm{N}$ (thus buffer zones are far from mountainous areas) with horizontal grid distance of $60 \mathrm{~km}$. The terrain height and land-use data for the given domain were generated from the United States Geographical Survey (USGS) global 30 minute resolution terrain and land-use data. The original monthly averaged optimum interpolation sea surface temperature (OISST) available from National Oceanic and Atmospheric Administration (NOAA) for the whole year was horizontally interpolated into the specified domain and also in each time step for the model integration. The lateral boundary conditions for wind, temperature, surface pressure and water vapor were interpolated from 6 hourly NCEP reanalysis product. Soil moisture was initialized according to vegetation specification (desert= dry) (Giorgi and Bates, 1989). The lateral boundary conditions were based on the relaxation method developed by Giorgi et al. (1993b). The lateral boundary conditions were updated and supplied every 6 hours into the model. The experiments were conducted for the Grell cumulus parameterization schemes with ArakawaSchubert as the closure scheme. These simulations are refered to the control experiment. Hereafter, we shall refer to control simulations in 1994, 2001, and 2002 as the CTL94, CTL01 and CTL02, respectively.

Inter-comparisons of RegCM3 simulated precipitation were made with the observed rainfall of Global Precipitation Climatology Center (GPCC-version -3). The gridded GPCC data (gauge based gridded monthly precipitation data) over global land surface are available in the spatial resolution of $1^{\circ} \times 1^{\circ}$ and $2.5^{\circ} \times 2.5^{\circ}$ geographical latitude by longitude. The gridded monthly precipitation data sets are freely available. They can be visualized in maps or downloaded in ASCII format using GPCC visualizer from the website (http:// gpcc.dwd.de). The details of GPCC data can be found in Fucsh et al. (2007).

In this study, nine years of data from NIMBUS-7 SMMR were used to compute the monthly mean values of snow depth in April over the Tibetan domain. The area chosen for snow input is $28^{\circ} \mathrm{N}$ to $40^{\circ} \mathrm{N}$ and $70^{\circ} \mathrm{E}$ to $100^{\circ} \mathrm{E}$. It may be noted that Ose et al. (1996) used the same domain of Tibet in their experiment. Using the nine years of NIMBUS-7 SMMR data, we calculated the monthly mean value of snow depth in April over the Tibetan domain and found the value of mean snow depth to be $0.10 \mathrm{~m}$ of water equivalent. Finally, two sets of experiments were performed. In one set, no initial snow over Tibet was prescribed to the model. This simulation was same as control experiment (CTL94, CTL01 and CTL02). In the other set, uniform snow of $0.10 \mathrm{~m}$ was prescribed over the Tibetan domain on 1 April each year and the model was integrated from 1 April to 1 October in 1994, 2001 and 2002. For brevity, we shall refer the integration with-snow experiments in the year 1994, 2001 and 2002 as SNOW94, SNOW01 and SNOW02, respectively. In both sets of experiments, the model generated its own snow during its integration, thereby making the process interactive. Total amount of simulated precipitation over India in both the CTL and SNOW experiments was then analyzed in detail.

\section{RESULTS AND DISCUSSION}

Indian summer monsoon has some unique characteristics such as cross equatorial flow from the Southern 
Hemisphere across the east African coast, LLJ flow over the Arabian Sea and the Indian peninsula, upper level Easterly Jet over the north Arabian Sea, and upper level anticyclone (at $200 \mathrm{hPa}$ ) over the Tibetan Plateau. India receives maximum amount of precipitation in July with a rapid decline in September as the monsoon withdraws from the northern parts of India. It is also important to note that ISMR in July has maximum contribution in deciding the total seasonal ISMR condition of deficient or excess rain years (Gadgil et al., 2002). Hence, the characteristic of monsoon com- ponents in July needs a separate study.

\subsection{Land-ocean contrast}

Land-ocean contrast is the basic mechanism for the development of south Asian monsoon systems. To study the land ocean contrast, we generally define a pressure Index (PI), which is defined as the difference in mean sea level pressure between two blocks (B2B1) (Kripalani et al., 2007). B2 is defined as area averaged mean sea level pressure over the regions such as equator $-5^{\circ} \mathrm{N}$ and $70^{\circ}-80^{\circ} \mathrm{E}$ (over ocean) whereas B1 is (a) Wind (m/s) July 1994 (NCEP)

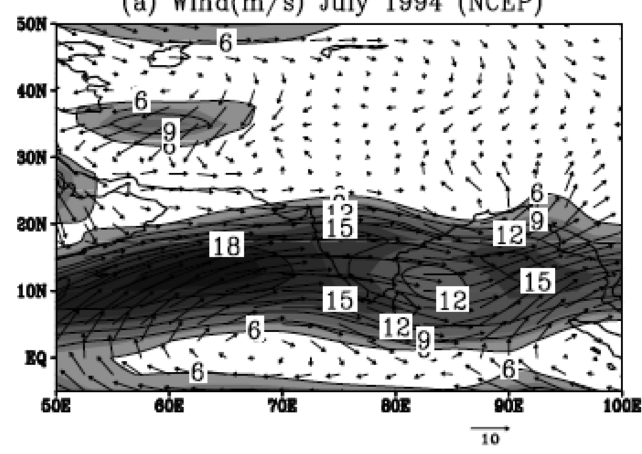

(c) Wind(m/s) July 2001 (NCEP)

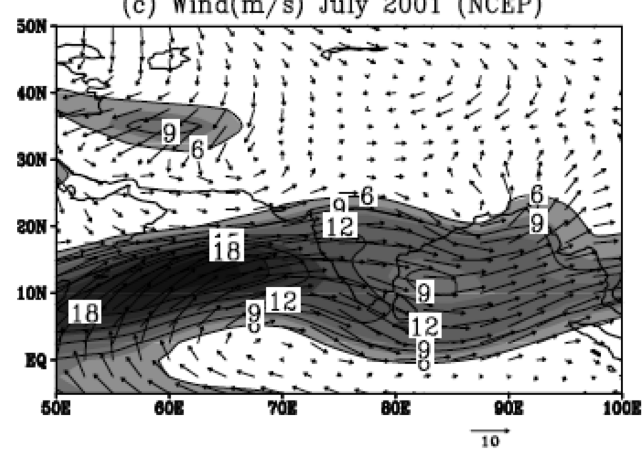

(e) Wind(m/s) July 2002 (NCEP)

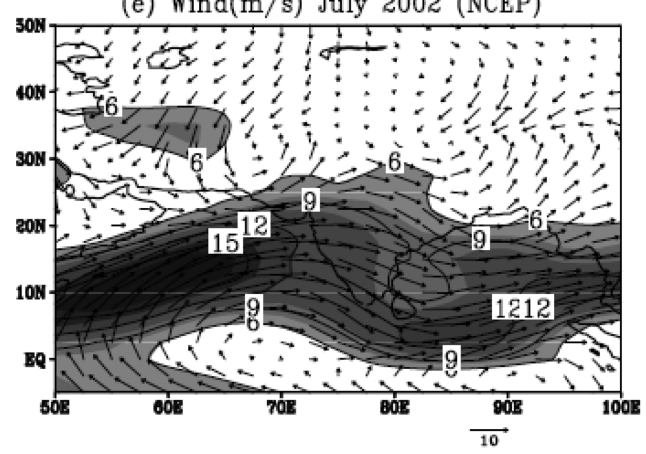

(b) $\operatorname{Wind}(\mathrm{m} / \mathrm{s})$ July 1994 (CTL94)

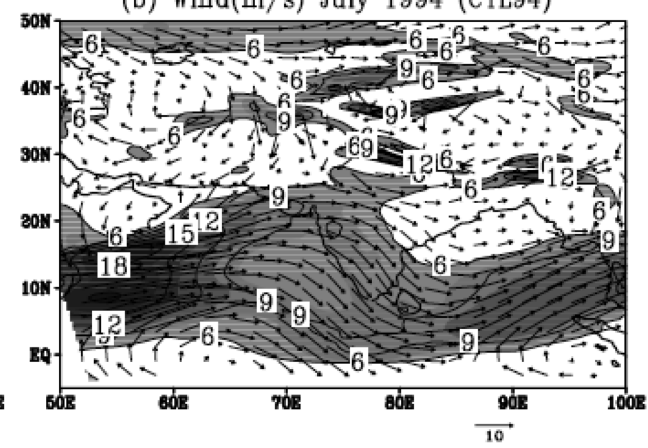

(d) Wind(m/s) July 2001 (CTL01)

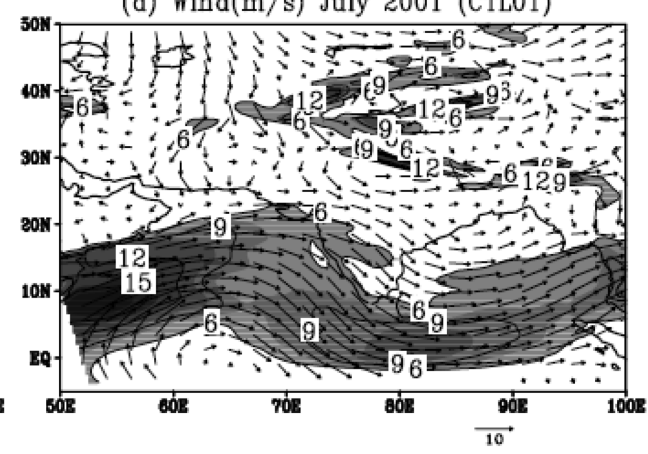

(f) Wind(m/s) July 2002 (CTL02)

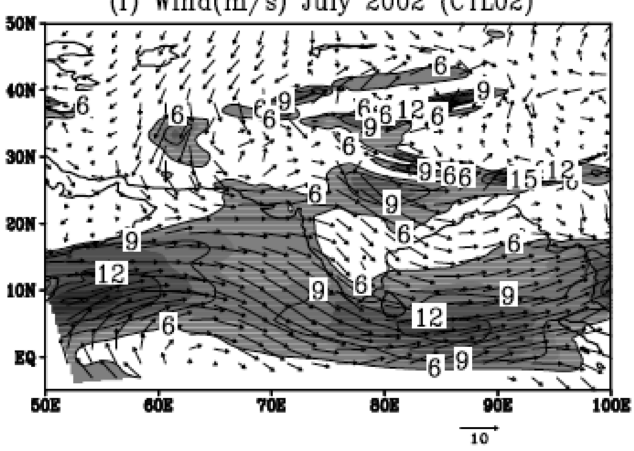

Fig. 1. The left and right panels refer to the observed (NCEP/NCAR reanalysis) and RegCM3 simulated winds ( $\mathrm{m} \mathrm{s}^{-1}$ ) during July at $850 \mathrm{hPa}$ : (a) and (b) for 1994, (c) and (d) for 2001, and (e) and (f) for 2002, respectively. Shaded regions indicate strong belt of monsoon westerlies. Contours intervals are at $3 \mathrm{~m} \mathrm{~s}^{-1}$ and wind less than $6 \mathrm{~m} \mathrm{~s}^{-1}$ are not shown. 
area averaged mean sea level pressure over $25^{\circ}-30^{\circ} \mathrm{N}$ and $70^{\circ}-80^{\circ} \mathrm{E}$ (over land). PI was computed for RegCM3 and NCEP in 1994, 2001 and 2002, resulting in 10.5 $\mathrm{hPa}(12 \mathrm{hPa}$ for NCEP), $10.9 \mathrm{hPa}$ (11.9 hPa for NCEP) and $12.1 \mathrm{hPa}(15.4 \mathrm{hPa}$ for NCEP) in CTL94, CTL01 and CTL02 experiments, respectively. Analysis shows that model underestimated the pressure gradient of 3.4 $\mathrm{hPa}$ in deficient rain years, $1.5 \mathrm{hPa}$ in excess rain year, and $1.0 \mathrm{hPa}$ in normal rain years. In summary, the land-ocean contrast captured by RegCM3 was weak especially in deficient rain years. This weakening may have been caused by cold bias of the model over large parts of the Indian subcontinent.

\subsection{Monsoon westerly:}

The left and right panels of Figs. 1(a-f) present the NCEP (reanalysis) product and RegCM3 simulated wind fields at $850 \mathrm{hPa}$ for CTL94, CTL01 and CTL02 experiments. Fig. 1 shows that the model well captured the basic flow patterns like cross equatorial flow, westerly flow over the Arabian Sea, the Indian peninsula, and the Bay of Bengal. It agreed well with the NCEP (observed) circulation patterns. Fig. 1 also showed a strong wind of $18 \mathrm{~m} \mathrm{~s}^{-1}$ (Fig. 1b) in CTL94 experi-

(b) Wind(m/s) July 1994 (CTL94)

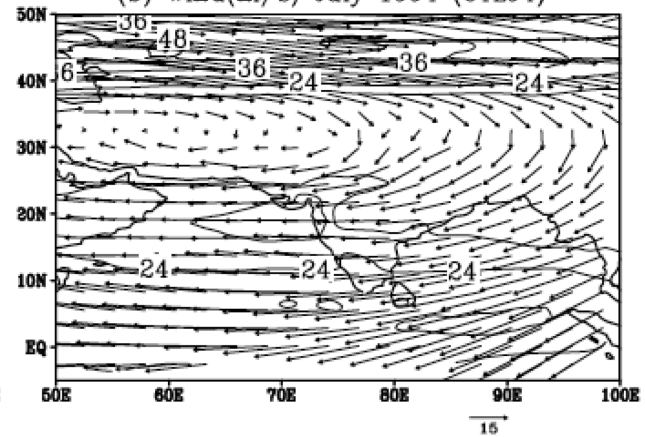

(d) Wind(m/s) July 2001 (CTL01)

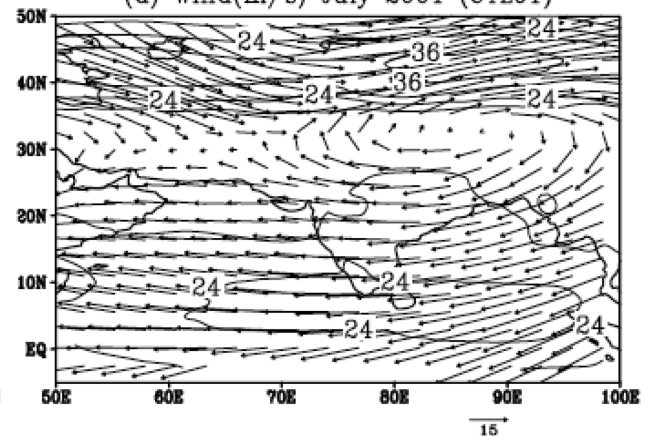

(f) Wind(m/s) July 2002 (CTLO2)

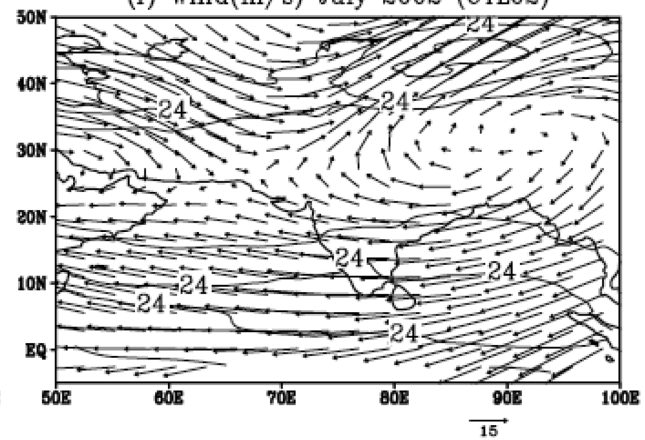

Fig. 2. Same as in the Fig. 1 except for wind at $200 \mathrm{hPa}$. Contours intervals are at $6 \mathrm{~m} \mathrm{~s}^{-1}$ and winds less than $12 \mathrm{~m} \mathrm{~s}^{-1}$ are not shown. 
ment and weaker wind of $12 \mathrm{~m} \mathrm{~s}^{-1}$ (Fig. 1f) in CTL02 experiment over the east coast of Africa. The south easterly trade winds across the south Indian Ocean and anticylonic circulation over the Arabian Sea was well captured in the model, but mean wind speeds were always weaker than the observed. The maximum wind speed over the central Arabian Sea (approximately $10^{\circ} \mathrm{N}$ and $65^{\circ} \mathrm{E}$ ) in RegCM3 was $10 \mathrm{~m} \mathrm{~s}^{-1}$ whereas NCEP wind speed exceeded $15 \mathrm{~m} \mathrm{~s}^{-1}$. This weakening may be associated with cold biases of the model over (a) July (62.5E-67.5E) OBS94

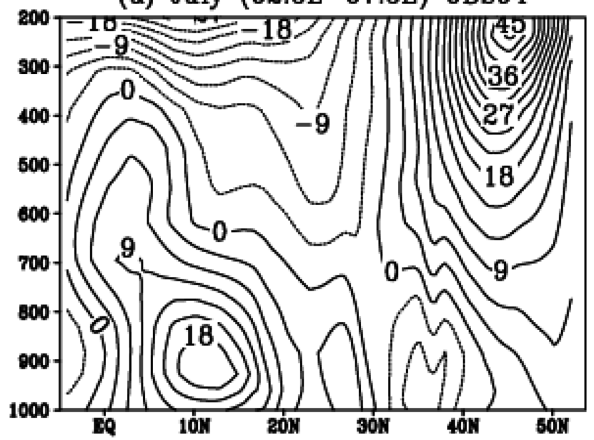

(c) July (62.5E-67.5E) OBS01

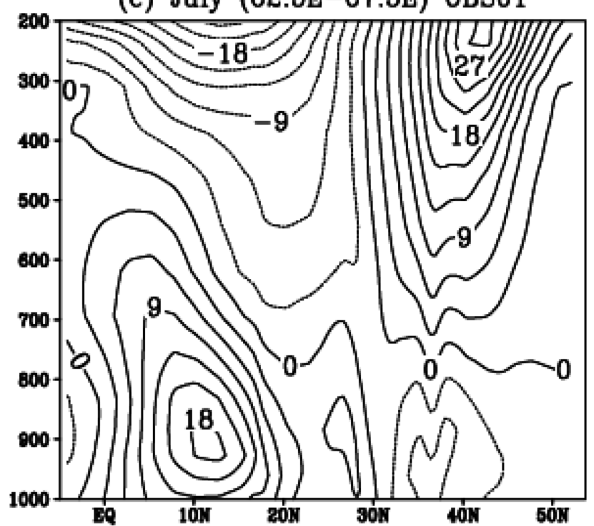

(e) July (62.5E-67.5E) OBSO2

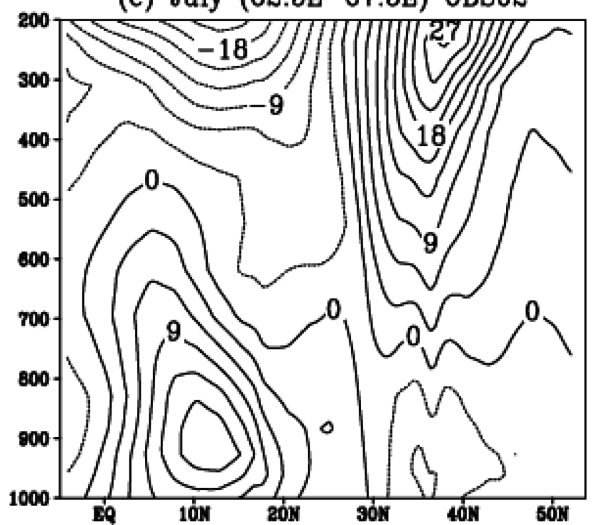

(b) July (75E-80E) oBS94

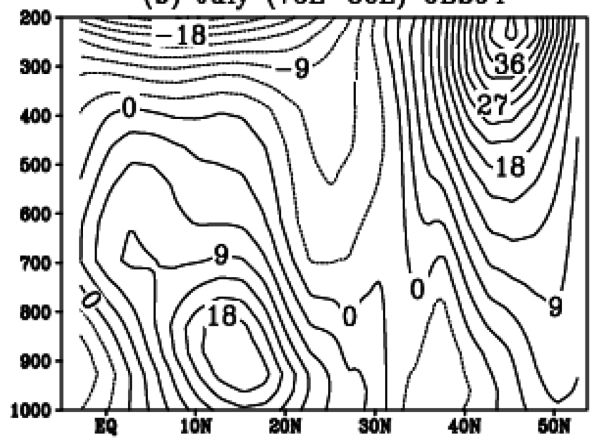

(d) July (75E-80E) OBS01

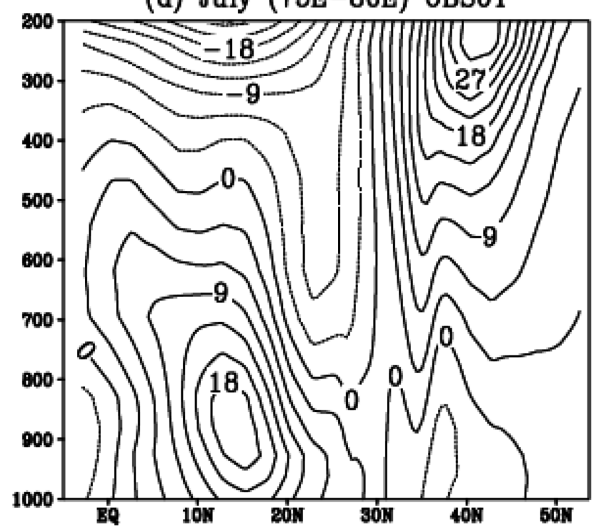

(f) July (75E-80E) OBS02

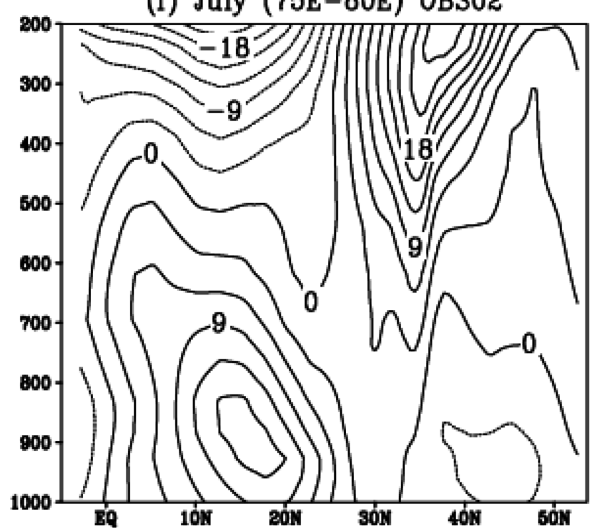

Fig. 3. The left and right panels show the vertical profile of the zonal component of wind $(\mathrm{m} / \mathrm{s})$ from NCEP (Observed) in July averaged over the longitude of $62.5 \mathrm{E}-67.5 \mathrm{E}$ (representative of longitude $65 \mathrm{E}$ ) and $75 \mathrm{E}-80 \mathrm{E}$ (representative of longitude $75 \mathrm{E}$ ): (a) and (b) for 1994, (c) and (d) for 2001 and (e) and (f) for 2002, respectively. 
large parts of Indian subcontinent. The cold biases in RegCM3 can be attributed to weak cross equatorial flow and hence weak monsoon westerly over the Arabian Sea and the Indian peninsula.

\subsection{Upper level tibetan high and tropical east- erly Jet}

The Tibetan High is a large anticyclone and shows its largest amplitude near $200 \mathrm{hPa}$ in northern summer. The upper level anticyclone first forms in April close to the north of Borneo. In July, it moves over the Tibetan highlands and becomes stronger. Another fascinating feature of the Indian summer monsoon systems is the upper level Tropical Easterly Jet. The strongest wind of upper level easterly jet is found close to the west of southern tip of India and over the Arabian Sea. Generally, jet forms in the month of June, intensified in July and present till September. The left panel of Fig. 2(a-f) presents the wind fields from NCEP and the right panel shows the simulated wind fields at upper level $(200 \mathrm{hPa})$. Fig. 2 (a and b) shows a huge anticyclone centered close to $70 \mathrm{E}$ in excess rain year, which was shifted slightly eastward in normal rain years (Fig. 2c and d). The RegCM3 simulation shows that upper level anticyclone became weak and broken into two cells, of which one was centered at $55^{\circ} \mathrm{E}$ and the other was centered at $90^{\circ} \mathrm{E}$ (Fig. 2f). Fig. 2(a-f) also shows an upper level easterly jet near latitude $10 \mathrm{~N}$. During excess rain year, easterly Jet covered large area with single cell while it was broken into more than one cell and covered slightly smaller area during deficient rain years (Fig. 2e and f) at $10 \mathrm{~N}$.

\subsection{Low Level Jet}

The low level cross equatorial jet is a well known northern summer low level jet (LLJ). Its importance has been recognized since the observational studies in Findlater (1971). The LLJ has the maximum wind speed at $850 \mathrm{hPa}$ in July. The zonal component of wind (U) fields at $850 \mathrm{hPa}$ over the Arabian Sea and the Peninsular India represent the LLJ. The observed (NCEP) and RegCM3 simulated mean vertical profiles of the zonal wind component of the summer monsoon flow over the central Arabian Sea and the Peninsular India and jet stream of the upper troposphere in July for CTL94, CTL01 and CTL02 experiments are shown in Figs. 3(a-f) and 4(a-f), respectively. Averaging has been done over the longitudes of $75^{\circ} \mathrm{E}-80^{\circ} \mathrm{E}$ for the Peninsular India and $62.5^{\circ} \mathrm{E}$ to $67.5^{\circ} \mathrm{E}$ for the central
Arabian Sea. Figs. 3(a-f) and 4(a-f) show monsoon westerly extended from surface to about $700 \mathrm{hPa}$ between the equator and $20^{\circ} \mathrm{N}$ over the central Arabian Sea (left panels) and between the equator and $25^{\circ} \mathrm{N}$ over the Peninsular India (right panels). A strong monsoon westerly can be seen in CTL94 (excess rain) experiment and slightly weaker westerly in CTL02 experiment (deficient rain) over the Arabian Sea. Figs. 3 and 4 also show that the westerly mean monsoon flow was strongest close to $850 \mathrm{hPa}$. The RegCM3 simulation shows that there were two cores of maximum wind speed over $65^{\circ} \mathrm{E}$ longitude: one is about $10^{\circ} \mathrm{N}$ and the other close to $17^{\circ} \mathrm{N}$ during the excess rain year while a single core of maximum wind speed over the same location in deficient rain year can be noticed. This result is in agreement with that of Findlater (1971). Another important result of this study is that the low level westerly at lower troposphere and easterly Jet in the upper troposphere over the Arabian Sea (Figs. 3 and Figs. 4) were well captured by RegCM3. A comparison of LLJ over the Peninsular India shows that model always underestimated the strength of LLJ compared to the NCEP. A strong westerly is found at lower level in 1994 (excess case) and weak westerly in 2002 (drought case). This is consistent with the result of Joseph and SijiKumar (2004) which has also shown strong westerly at lower level during the active monsoon years and weak westerly in weak monsoon year based on the empirical study.

\subsection{Precipitation}

The precipitation is shown only for the interior of the domain in order to illustrate the fine scale with topographically induced details. The right panels of Fig. 5(a-f) present the simulated precipitation and the left panels display the observed precipitation from GPCC in 1994, 2001 and 2002, respectively. The simulated precipitation in CTL94 experiment (Fig. 5b) shows high precipitation that covers larger parts of India compared to the CTL02 experiment (Fig. 5f). Similarly, the observed precipitation from GPCC (Fig. 5a) also shows high precipitation that covers larger parts of the Indian subcontinent in 1994 (excess rain year) compared to 2002 (deficient rain year) (Fig. 5e). The observed precipitation also shows a belt of maximum precipitation over the western Ghat and over the head Bay of Bengal, whereas the RegCM3 shows the zones of maximum precipitation over the Arabian Sea, central Bay of Bengal, foot hills of Himalayas (north-east) 
(a) July (62.5E-67.5E) CTL94

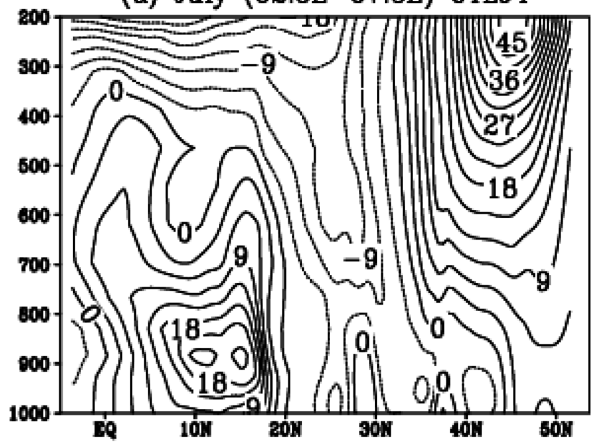

(c) July (62.5E-67.5E) CTL01

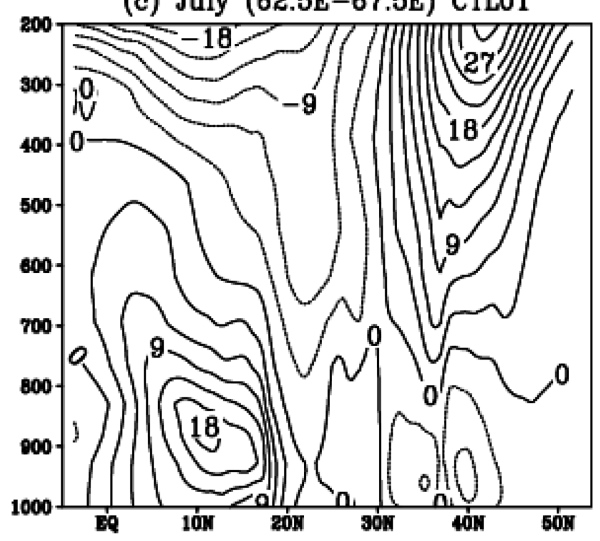

(e) July (62.5E-67.5E) CTL02

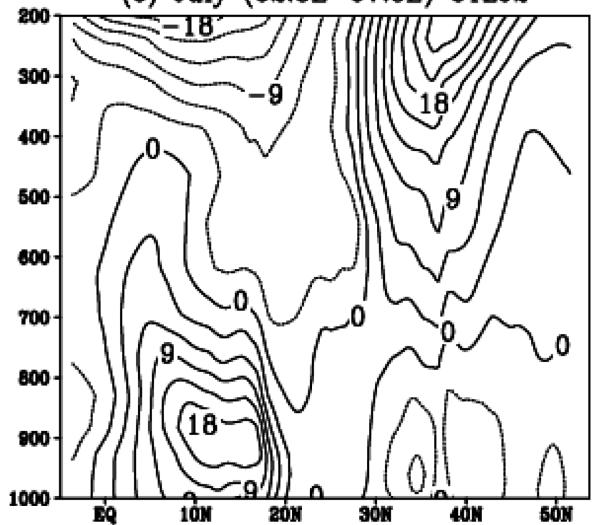

Fig. 4. Same as in the Fig. 3 except for the RegCM3.

and over the west Ghat. The RegCM3 simulation also shows high precipitation over the Arabian Sea and Bay of Bengal. The rainfall over the ocean is generally caused by convective activity; therefore high precipitation over the ocean may be associated with physical parameterization of convections in RegCM3 possibly (b) July (75E-80E) CTL94

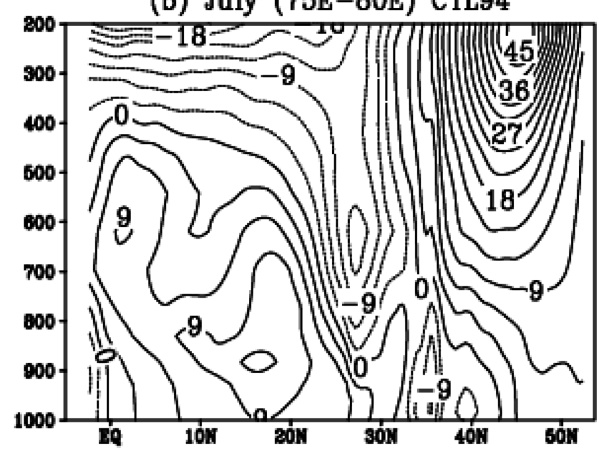

(d) July (75E-80E) CTL01

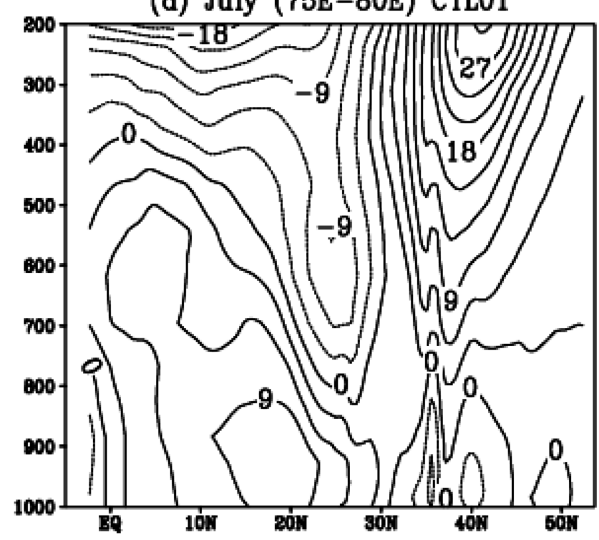

(f) July (75E-80E) CTL02

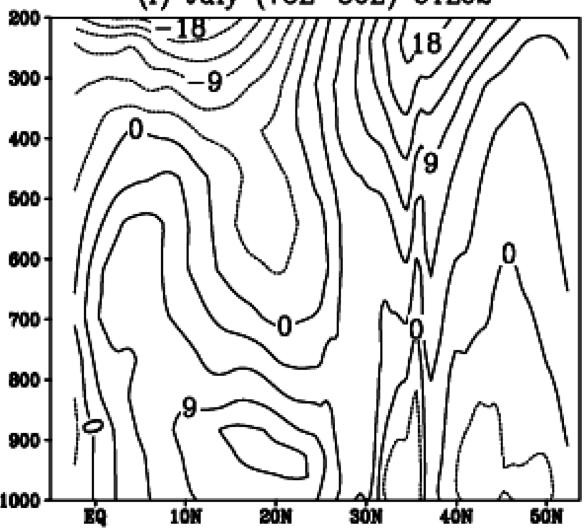

in combination with parameterization of other related processes. Overall, the RegCM3 results show that the model was able to capture the zone of high and low precipitation during excess and deficient rain years but the amount of precipitation in RegCM3 was always lower than the observed especially over the western 
(a) Rainfall(cm/month) July GPCC94

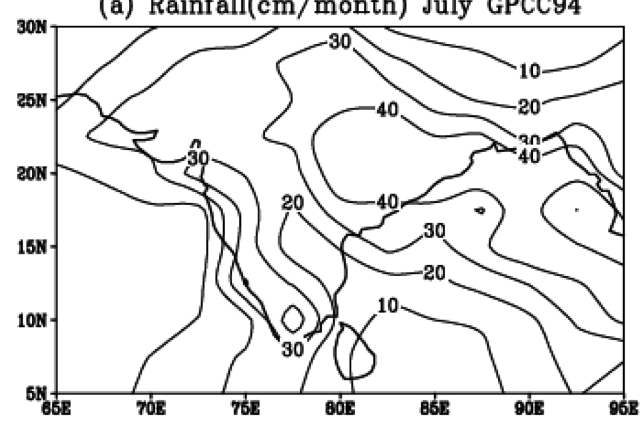

(c) Rainfall(cm/month) July GPCC01

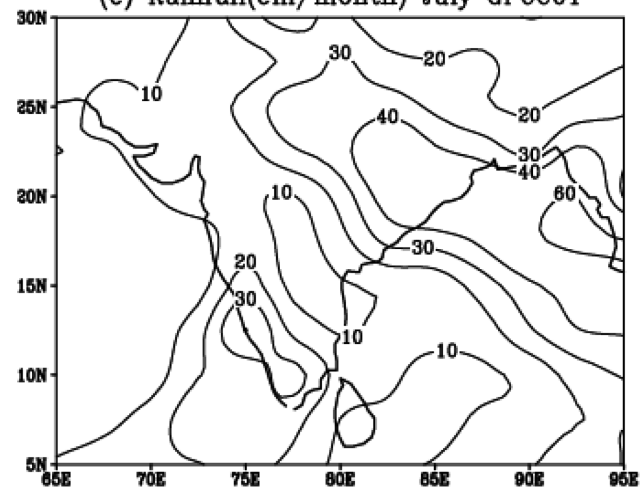

(e) Rainfall(cm/month) July GPCC02

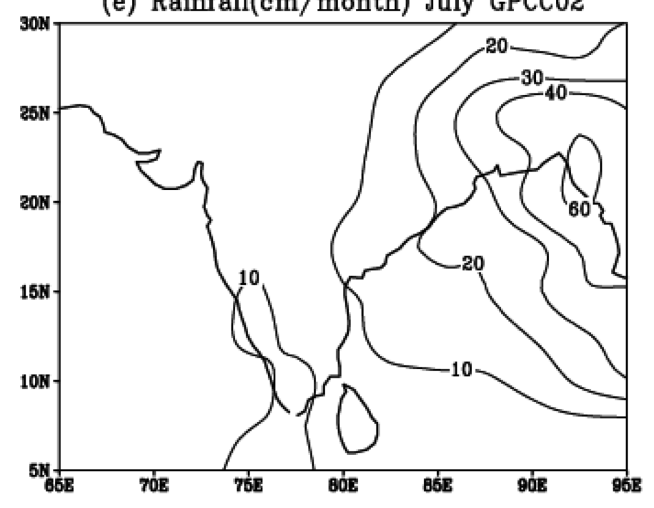

(b) Rainfall(cm/month) July CTL94

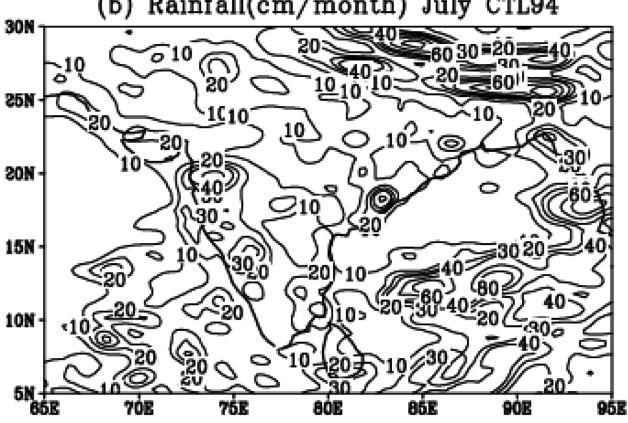

(d) Rainfall(cm/minth) July CTL01

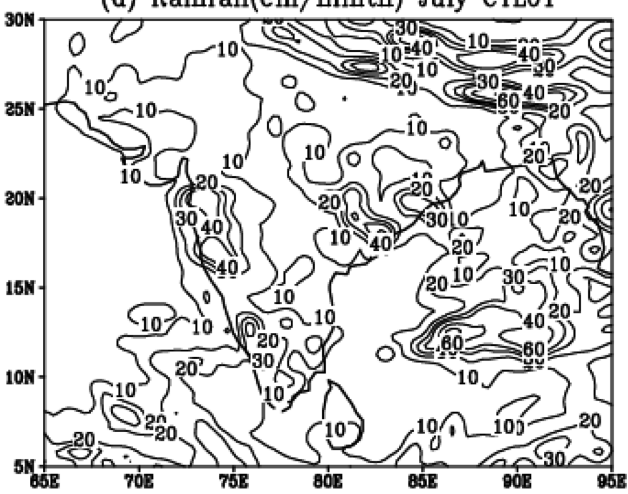

(f) Rainfall(cm/month) July CTL02

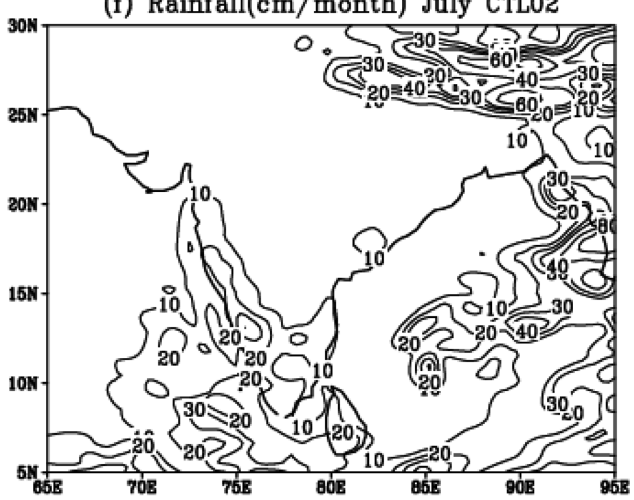

Fig. 5. The left and right panels show the observed precipitation from GPCC (Global Precipitation Climatology Centre) and RegCM3 simulated precipitation (cm) in July: (a) and (b) for 1994, (c) and (d) for 2001, and (e) and (f) for 2002, respectively.

Ghat. The precipitation over the western Ghat was highly influenced by the strength of monsoon westerly and LLJ. The low precipitation over the western Ghat may be due to underestimation of strength of monsoon westerly and LLJ in RegCM3. The spatial distribution of high precipitation in 1994 (Fig. 5b) and low precipitation in 2002 (Fig. 5f) over the large parts of India is well captured by the RegCM3.

\subsection{Some inferences from band pass filter}

We have investigated the temporal characteristics of the 3-7 days, 10-20 days and 30-60 days oscillations of ISMR from June to August in 1994 and 2002 (i.e. two extreme cases). Daily rainfall data for India as a whole (day to day rainfall based on approximately 150 stations) were collected from All India weather summary prepared by the India Meteorological Department (IMD). 
For examining these oscillations, Butterworth band pass filter was applied (Murakami, 1979). It is well known that the precipitation distribution over India varies considerably from day to day. Over major parts, rain occurs in spells under the influence of different circulation conditions. The intermittent behavior of rain is generally associated with a hierarchy of quasi-periods of 3-7 days, 10-20 days and 30-60 days. The 3-7 days periodicity is associated with the oscillation of monsoon trough, while 10-20 days periodicity is associated with the synoptic scale systems formed over the Bay of Bengal and usually propagates towards northwest and produces substantial rainfall. Finally, 30-60 days periodicity is associated with the globally eastward moving wave number 1 and 2 in the tropics. The details about the computational procedures are well described in Kripalani et al. (2004). The analysis shows that the variance of the observed precipitation was $16.4 \%$ and $15.5 \%$ in 1994 and $13.2 \%$ and $8.4 \%$ in 2002 for faster modes (3-7 days and 10-20 days, respectively). For slower mode (30-60 days), the observed variance was $7.6 \%$ and $16.5 \%$ in 1994 and 2002, respectively. On the other hand, RegCM3 shows the variance of $15.8 \%$ and $11.5 \%$ in 1994 and $11.6 \%$ and $16 \%$ during 2002 for faster (3-7 days and 10-20 days) mode whereas for slower (30-60 days) mode it was $9.2 \%$ in 1994 and $22.4 \%$ in 2002 . In summary, the observed precipitation shows that the variance in the faster modes was higher in excess rain year compared to deficient rain year. Similarly, the variance in slower mode (30-60 days) was higher in deficient rain year compared to excess rain year. This is consistent with the results of Kripalani et al. (2004) based on the observed data.

\subsection{Sensitivity experiments}

It is important to note that ISMR has significant temporal as well as spatial variability. India as a whole is too large to be treated as a single unit. Walker (1928) had suggested that ISMR over different subdivision of India should be grouped together to define area averaged for large homogeneous zones on the basis of uniformity of correlation coefficient between the ISMR anomalies and atmospheric global parameters (e.g., Eurasian snow, southern oscillation Index, El-Nino). It is not uncommon to find some areas of deficient ISMR even with excess rain years at all India and vice-versa. Therefore, it is always advisable to consider homogeneous zones for better understanding of ISMR. The details about homogeneous zones of India can be seen in Singh and Sontakke (1996).

It is well known that snow acts as one of the important factors for the development and maintenance of the Indian summer monsoon system. The Tibetan Plateau, due to its elevation, receives a huge amount of solar radiation in summer, which heats up the mountain surface and creates a strong heat contrast at the mid tropospheric level. This causes a heat low near the surface and high (i.e., the Tibetan High) in the upper atmosphere (Murakami 1987). The Tibetan Plateau acts as a heat source/sink for the Indian monsoon cir-

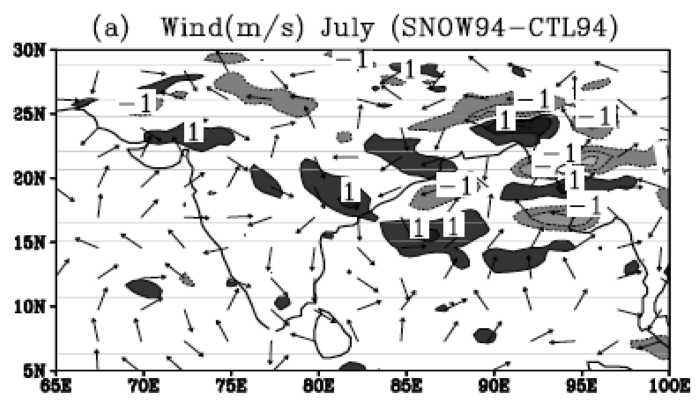

(b) Wind $(\mathrm{m} / \mathrm{s}$ ) July (SNOW01-CTL01)

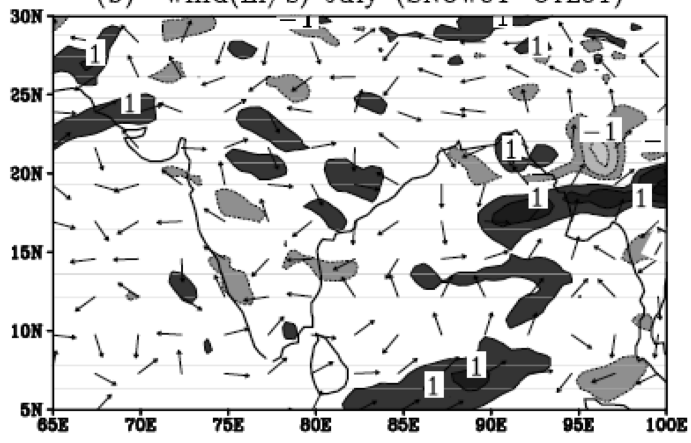

(c) Wind (m/s) July (SNOWO2-CTLO2)

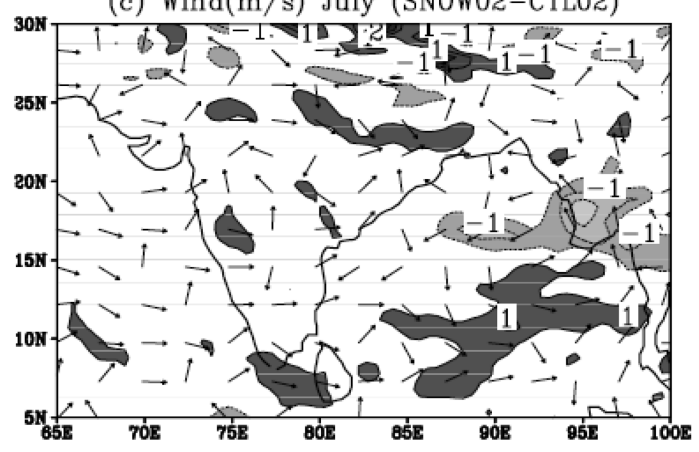

Fig. 6. Difference in wind fields $\left(\mathrm{m} \mathrm{s}^{-1}\right)$ between the SNOW (with snow) and control (no-snow) experiments during July in (a) 1994, (b) 2001 and (c) 2002, respectively. 
culation in summer and winter seasons. In this section, we have analyzed the wind field at $850 \mathrm{hPa}$ and precipitation over different homogeneous zones of India as affected by the initial snow in SNOW (with-snow)

(a) Rainfall(cm/month) July (SNOW94-CTL94)

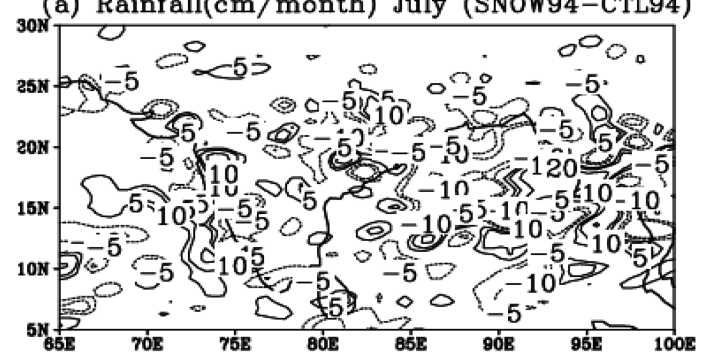

(b) Rainfall(cm/month) July (SNOW01-CTL01)

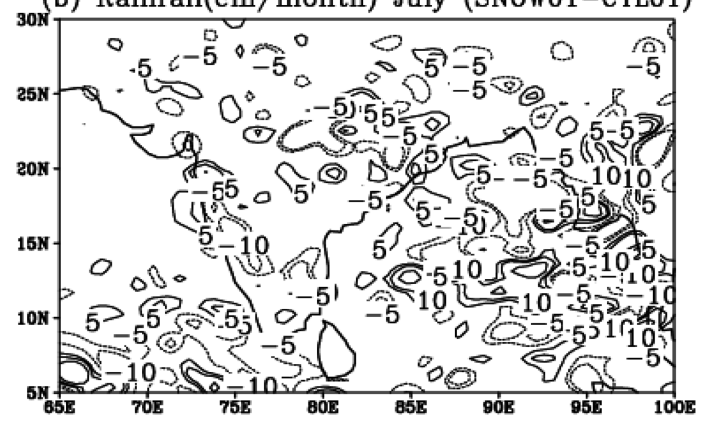

(c) Rainfall(cm/month) July (SNOW02-CTLO2)

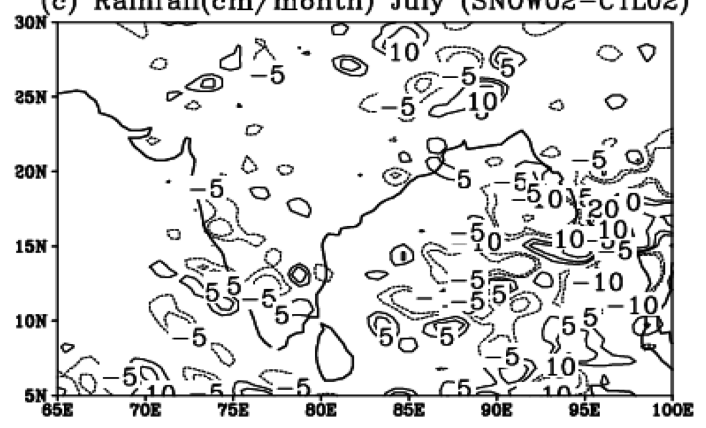

Fig. 7. Same as in the Fig. 6 except for precipitation $(\mathrm{cm})$. experiments. Fig. 6 (a-c) shows the difference in the wind fields at $850 \mathrm{hPa}$ between the SNOW (withsnow) and CTL (no-snow) experiment in July 1994, 2001 and 2002. The difference in wind field shows that the easterlies (weak westerly in high snow cases) at $850 \mathrm{hPa}$ dominated over the Indian Peninsula in the SNOW experiment compared to the control experiments (Fig. 6). Similarly, the difference in the wind field at $200 \mathrm{hPa}$ (not shown) showed weaker upper level easterly Jet over the Arabian Sea and the Indian Peninsula in the SNOW experiment.

The difference in precipitation between the SNOW and CTL experiments is shown in Fig. 7(a-c), which depicts low precipitation in the SNOW experiments compared to the CTL experiments during July of 1994, 2001 and 2002 over the major parts of Indian subcontinent. The maximum decrease in precipitation is noticed over the northeast India and the south Pen-

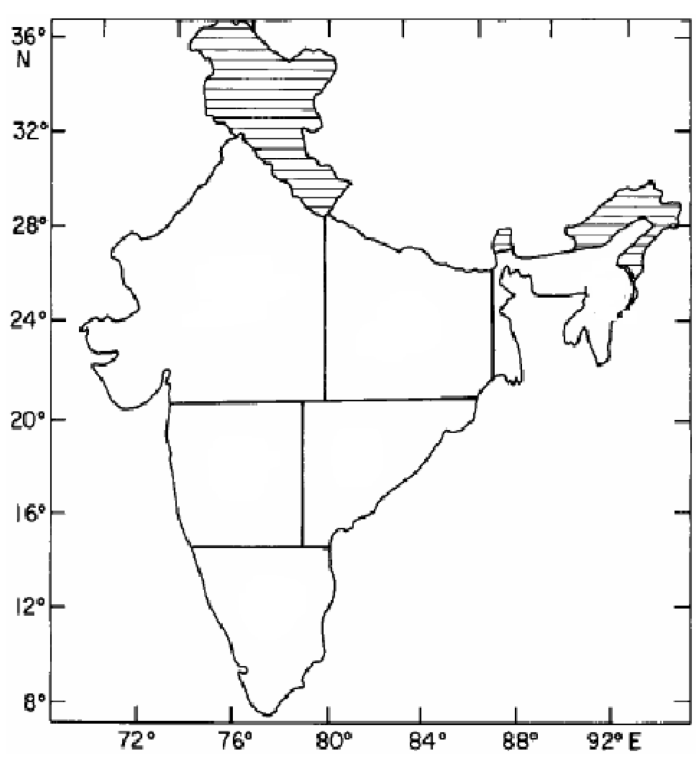

Fig. 8. Locations of homogeneous zones.

Table 1. Area averaged precipitation ( $\mathrm{cm} / \mathrm{month})$ in July over six homogeneous zones of India

\begin{tabular}{crcccccc}
\hline \hline \multirow{2}{*}{$\begin{array}{c}\text { Homogeneous } \\
\text { zones of India }\end{array}$} & \multicolumn{3}{c}{ Control (no-snow) } & & \multicolumn{3}{c}{ SNOW (with-snow) } \\
\cline { 2 - 4 } \cline { 6 - 8 } \cline { 5 - 7 } & 2002 & 1994 & 2001 & & 2002 & 1994 & 2001 \\
\hline NWI & 4.4 & 21.4 & 18.3 & & 6.0 & 16.4 & 20.0 \\
WPI & 5.9 & 17.7 & 15.5 & & 4.8 & 13.3 & 16.2 \\
SPI & 27.3 & 37.5 & 28.5 & & 24.5 & 22.7 & 31.3 \\
NCI & 13.3 & 18.9 & 14.1 & & 15.0 & 20.1 & 22.3 \\
EPI & 17.4 & 44.3 & 59.9 & & 21.2 & 52.3 & 40.5 \\
NEI & 100.8 & 99.8 & 71.3 & & 50.0 & 52.1 & 54.0 \\
\hline
\end{tabular}


insular India. This decrease in precipitation can be related with weaker westerly at $850 \mathrm{hPa}$ and weaker easterly Jet at $200 \mathrm{hPa}$ in the SNOW experiments. Thus, the precipitation pattern resembles well the monsoon circulation patterns over the Indian subcontinent. For better understanding of the effect of snow on the regional monsoon rainfall, we have computed the area averaged precipitation (Table 1) over six homogeneous zones of India: the northwest India (NWI), the west Peninsular India (WPI), the south Peninsular India (SPI), the north central India (NCI), the east Peninsular India (EPI), and the northeast India (NEI). Locations of homogeneous zones are shown in Fig. 8.

Table 1 shows a major reduction in precipitation over the NEI and a moderate reduction over the SPI in 1994, 2001 and 2002. Minor reduction can be seen over the NWI and the WPI (in 2001 and 1994) and increased precipitation over the NCI in 1994, 2001 and 2002. In general, the results of the sensitivity experiments indicate that the Tibetan snow in April generally weakens the monsoon westerly at lower level and easterly Jet at upper level during the following summer monsoon over the Indian subcontinent. The RegCM3 simulation also shows that when $0.10 \mathrm{~m}$ of snow depth is prescribed over Tibet in April, ISMR reduces. This indicates that RegCM3 responds to changes in the snow depth reasonably well. The weakening of ISMR due to spring snow can be related to an excessive snowfall in previous spring which can delay the buildup of the important monsoonal temperature gradient. This is because a part of the solar energy is reflected and other part is utilized for melting of snow or evaporating the soil moisture. A relatively small amount of net solar energy is left for warming the surface and hence the atmosphere.

\section{CONCLUSIONS}

Although the RegCM modeling system has been widely used for various regional climate studies (Giorgi and Mearns, 1999), it has not been extensively tested over the South Asia region, particularly concerning the component of the Indian summer monsoon system. In this paper, RegCM3 has been integrated over the Indian region to (i) evaluate the model performance in simulating some of the components of the Indian summer monsoon systems under different ISMR conditions and (ii) investigate the impact of the spring snow depth over Tibet on the following summer monsoon circulation and rainfall over India.

Results indicate that RegCM3 captures some of the important characteristics of the Indian summer monsoon circulation such as westerly at lower level, low level jet, Tibetan High, and easterly Jet at upper level. Also, spatial precipitation distribution and zones of high precipitation simulated in RegCM3 were comparable to the corresponding observed precipitation. Although the amount of precipitation simulated in RegCM3 was lower than the observation, the model also captured the variances in intra seasonal oscillation during the excess and deficient rain years. Sensitivity experiments indicate that the spring snow depth over Tibet weakened the low level westerly and upper level easterly over India during the subsequent summer monsoon. The prescription of $0.10 \mathrm{~m}$ initial April snow depth over Tibet lead to a reduction in rainfall mainly over the south Peninsular India and northeast India. Such a reduction in precipitation can be associated with weaker westerly at lower level and weaker easterly Jet at upper level, respectively.

\section{적 요}

아시아 주요 곡물 생산지의 경제 성장과 지표 이용 변화에 따른 인간 활동의 증가는 아시아 몬순의 경향 을 변화 시켰다. 본 연구에서는 지표-해양 대비, 하층 제트 기류(LLJ), 티벳 고층 및 상층 편동풍 제트 기 류를 포함한 인도 여름 몬순의 중요한 구성 요소를 모사하여 지역기후 모형 ( $\mathrm{RegCM} 3)$ 의 성능을 평가하 였다. 3년(1994: 다우 해, 2002: 평균 해, 2002: 가 뭄 해)의 비교 자료를 선택하여 RegCM3은 매년 4월 1 일부터 10 월 1 일까지 $60 \mathrm{~km}$ 의 해상도로 적분하였다. 순환과 강수 모사 결과는 $\mathrm{NCEP} / \mathrm{NCAR}$ 재해석 자료 와 Global Precipitation Climatology Centre(GPCC)의 관측 자료로 검증하였다. RegCM3 모형 모사의 중요 결과는 다음과 같다. (a) LLJ 는 다소 강하였으며 아 라비아해에서 다우 해에 두 개로 분할되었으나, 평균 및 가뭄 해에서는 분할되지 않았다. (b) 단일의 대형 고기압이 다우 해에 존재하였으나, 가뭄 해에는 약하고 두 개의 고기압대로 분할되었다. (c) 강수의 공간분포 모사는 대부분 인도 지역에서 $\mathrm{GPCC}$ 의 관측 강수량과 유사하였다. (d) NIMBUS-7 SMMR 적설 자료를 이 용한 민감도 실험에서 북동 및 남부 인도 반도 지역 에서 주로 강수량의 감소가 나타났으며, 티벳 지역에서 는 4월 적설량이 $0.1 \mathrm{~m}$ 감소하는 것으로 나타났다. 


\section{ACKNOWLEDGEMENTS}

Authors are very much thankful to the anonymous reviewers for giving valuable comments and constructive suggestions on this paper. We are grateful to Dr. F. Giorgi and Jeremy Pal, Physics of Weather and Climate group, ICTP, Trieste, Italy for their encouragement. This work was funded by the Department Science and Technology, Government of India (No. SR/AS/05/ 2008). The first author also wants to acknowledge the CATER for supporting the visit at Pukyong National University, Busan, South Korea.

\section{REFERENCES}

Annamalai, H., J. M. Slingo, K. R. Sperber, and K. Hodges, 1999: The mean evolution and variability of the Asian summer monsoon : Comparison of ECMWF and NCEP/ NCAR reanalysis. Monthly Weather Review 127, 11571186.

Barnet, T. P., L. Dumenil, U. Schlese, E. Roeckner, and M. Latif, 1989: The effect of Eurasian snow cover on regional and global climate variations. Journal of the Atmospheric Sciences 46, 661-685.

Bhaskaran, B. R., G. Jones, J. M. Murphy, and M. Noguer, 1996: Simulations of the Indian summer monsoon using a nested regional climate model: Domain size Experiments. Climate Dynamics 12, 573-578.

Chattopadhyay, J., and R. Bhatla, 2002: Possible influence of QBO on teleconnection relating Indian summer rainfall and SST anomalies across the equatorial Pacific. International Journal of Climatology 22, 121-127.

Cocke, S., and T.E. LaRow, 2000: Seasonal predictions using a regional spectral model embedded within a coupled ocean-atmosphere model. Monthly Weather Review 128, 689-708.

Dash, S. K., M. S. Shekhar, and G. P. Singh, 2006: Simulation of Indian Summer monsoon Circulation and rainfall using RegCM3. Theoretical and Applied Climatology 86, 161-172

Dickinson, R. E., R. M. Erico, F. Giorgi, and G. T. Bates, 1989: A regional climate model for the western United states. Climate Change 15, 383-422.

Fennessy, M. J., and J. Shukla, 2000: Seasonal prediction over North America with a regional model nested in a global model. Journal of Climate 13, 2605-2627.

Findlater, J., 1971: Mean monthly air flow at low levels over the western Indian Ocean. Geophysics Memoirs 16(115), 1-53.

Fucsh, T., U. Schneider, and B. Rudolf, 2007: Global Precipitation Analysis Product of the Global Precipitation Climate Center (GPCC). Deutscher Wetterdienst, Offen- bach a.m. Germany, March 2007 (www.dwd.de/en/FundE/ Klima/KLIS/int/GPCC).

Gadgil, S., J. Srinivasan, R. S. Nanjundiah, K. Krishna Kumar, A. A. Munot, and K. Rupa Kumar, 2002: On the forecasting the Indian summer monsoon: the intriguing season of 2002. Current Science 83, 394-403.

Gao, Xiaogang, S. Sorooshian, and H. V. Gupta, 1996: Sensitivity analysis of the biosphere-atmosphere transfer scheme. Journal of Geophysical Research 101, 72797289.

Giorgi, F., and G. T. Bates, 1989: The climatological skill of a regional model over complex terrain. Monthly Weather Review 117, 2325-2347.

Giorgi, F., M. R. Marinucci, and G. T. Bates, 1993a: Development of a second generation regional climate model (RegCM2) I, Boundary layer and radiative transfer processes. Monthly Weather Review 121, 2794-2813.

Giorgi, F., M. R. Marinucci, and G. T. Bates, 1993b: Development of a second generation regional climate model (RegCM2) II, Convective processes and assimilation of lateral boundary conditions. Monthly Weather Review 121, 2814-2832.

Giorgi, F., C. Shields Brodeur, and G. T. Bates, 1994: Regional Climate Change scenarios over the United States produced with a nested regional climate model. Journal of Climate 7, 375-399.

Giorgi, F., and L. O. Mearns, 1999: Introduction to special section: regional climate modeling revisited. Journal of Geophysical Research 104, 6335-6352.

Grell, G. A., 1993: Prognostic evaluation of assumptions used by cumulus parametisations. Monthly Weather Review 121, 764-787.

Grell, G. A., J. Dudhia, and D. R. Stauffer, 1994: A description of fifth generation Penn State/NCAR Mesoscale Model (MM5). NCAR Technical Notes NCAR/TN-398+STR, $21 \mathrm{pp}$.

Holtslag, A. A. M., E. I. F.de Bruijin, and H. L. Pan, 1990: A high resolution air mass transformation model for short range weather forecasting. Monthly Weather Review 118, 1561-1575.

Hsie, E. Y., R. A. Anthes, and D. Kiyser, 1984: Numerical simulation of frontogenesis in a moist atmosphere. Journal of the Atmospheric Sciences 41, 2581-2594.

Joseph, P. V., and S. Sajikumar, 2004: Intraseasonal variability of the Low Level Jet stream of the Asian Summer monsoon. Journal of Climate 17(7), 1449-1458.

Kiehl, J., J. Hack, G. Bonan, B. Boville, B. Breigleb, D. Williamson, and P. Rasch, 1996: Description of the NCAR Community Climate Model (CCM3). Technical Report, National Center for Atmospheric Research.

Kripalani, R. H., A. Kulkarani, S. S. Sabade, J. V. Revadekar, S. K. Patwardhan, and J. R. Kulkarani, 2004: Intraseasonal oscillation during monsoon 2002 and 2003. Current cience $\mathbf{8 7}$, 325-331. 
Kripalani, R. H., J. H Oh, A. Kulkarani, S. S. Sabade, and H. S. Chaudhary, 2007: South Asian summer monsoon precipitation variability:Coupled climate model simulations and projection under IPCC AR4. Theoretical and Applied Climatology 90, 133-159.

Luo, H., and M. Yanai, 1983: The large scale circulation and heat sources over the Tibetan Plateau and surrounding areas during the early summer of 1979. Part-I: Precipitation and kinemetic analysis. Monthly Weather Review 111, 922-944.

Lynn, Barry H., R. Healy, and L. M. Druyan, 2007: An Analysis of the Potential for Extreme Temperature Change Based on Observations and Model Simulations. Journal of climate 20, 1539-1554.

Mitchell, K., M. J. fenessy, E. Rogers, J. Shukla, T. Black, J. Kinter, F. Mesinger, Z. Janjic, and E. Altshuler, 2001: Simulation of North American summer time climate with the NCEP ETA model nested in the COLA GCM. Global Energy and water Cycle Experiment (GEWEX) Newsletter 11, 3-6.

Murakami, M., 1979: Recursion technique for Band pass filter. Monthly Weather Review 107, 1011-1012.

Murakami, T., 1987: Orography and monsoons. Monsoons, Fein and Stephens (Eds), Wiley-Interscience, 331-364.

Nobre, P., A. D. Moura, and L. Sun, 2001: Dynamical downscaling of seasonal climate prediction over Nordeste Brazil with ECHAM3 and NCEP's regional spectral models at IRI. Bulletin of the American Meteorological Society 82, 2787-2796.

Ose, T., 1996: The comparision of the simulated response to the regional snow mass anomalies over Tibet, Eastern Europe and Siberia. Journal of the Meteorological Society of Japan 74, 845-866.

Pal, J., and S. E. Eltahir, 2000: Simulation of regional scale water and energy budgets: Representation of subgrid cloud and precipitation processes within RegCM. Journal of Geophysical Research 105, 29579-29594.

Parthasarathy, B., A. A. Munot, and D. R. Kothawale, 1995:
Monthly and seasonal rainfall series for All India homogenous regions and meteorological sub-divisions 1871-1994. IITM Research Report 65, Indian Institute of Tropical Meteorology, Pune India, 113pp.

Roads, J., S.-C. Chen, M. Kamamitsu, 2003a: U. S. regional climate simulations and seasonal forecasts. Journal of Geophysical Research 108, 8606, doi:10.1029/2002JD002232.

Singh, G. P., J. H. Oh, and H. S. Chaudhary, 2005: Difference in large scale circulation characteristics between deficient and excess Indian summer monsoon rainfall year. Journal of the Korean Meteorological Society 41, 285-300.

Singh, G. P., and J. H. Oh, 2007: Impact of Indian Ocean sea surface temperature anomaly on Indian summer monsoon precipitation using a regional climate model. International Journal of Climatology 27, 1455-1465.

Singh, N. N., and N. A. Sontakke, 1996: On the variability and prediction of rainfall in the post monsoon season over India. International Journal of Climatology 19, 309339.

Vernekar, A. D., J. Zhou, and J. Shukla, 1995: The effect of Eurasian snow cover on the Indian monsoon. Journal of Climate 8, 248-266.

Walker, G. T., 1928: Correlation in seasonal variation of weather. Quarterly Journal of the Royal Meteorological Society 44, 223-224.

Wang, Y., L. R. Leung, J. L. McGREGOR, D. K. Lee, W. C. Wang, Y. Ding, and F. Kimura, 2004: Regional climate modeling: Progress, challenges and prospects. Journal of the Meteorological Society of Japan 82, 1599-1628.

Yasunari, T., A. Kitoh, and T. Tokioka, 1991: Local and remote response to excessive snow mass over Eurassia appearing in the northern spring and summer climate- a study of the MRI GCM. Journal of the Meteorological Society of Japan 69, 473-487.

Zwiers, F., 1993: Simulation of the Asian Summer monsoon with the CCC GCM-1. Journal of Climate 6, 470486. 